ISSN = 1980-993X - doi:10.4136/1980-993X
www.agro.unitau.br/ambi-agua
E-mail: ambi-agua@agro.unitau.br
Tel.: (12) 3625-4116

\title{
Kinetics of zinc toxicity to environmental bacterial isolates
}

(doi:10.4136/ambi-agua.100)

\author{
Christian O. Nweke \\ Department of Microbiology, Federal University of Technology, P.M.B. 1526, Owerri, Nigeria \\ E-mail: xrisokey@yahoo.com
}

\begin{abstract}
Toxicity of zinc to Pseudomonas, Escherichia, Proteus, Bacillus and Arthrobacter species isolated from a tropical river and petroleum refinery effluent was assessed using TTCdehydrogenase activity (DHA) inhibition test. At sufficient concentrations, zinc is toxic to these bacterial cells, and the exposure of the cells to zinc ion resulted in repression of dehydrogenase activity. The patterns of these toxic effects can be mathematically described with logistic dose-response models and in a manner similar to the non-competitive inhibition of enzymes. The threshold concentration above which toxic effect is observed ranged from $0.008 \mathrm{mM}$ for Pseudomonas sp. DAF1 to $0.364 \mathrm{mM}$ for Proteus sp. PLK2. The coefficients of inhibition $K_{i}$ correlated with the $\mathrm{IC}_{50}$ and indicate that zinc toxicity is dependent on the organism. The $K_{i}$ and toxicity threshold values predicted from the equations are comparable and are suitable indicators for kinetic analyses of zinc toxicity against bacteria.
\end{abstract}

Keywords: Zinc; dehydrogenase activity; toxicity thresholds; refinery effluent; inhibition coefficient.

\section{Cinética da toxicidade de zinco para isolados ambientais de bactérias}

\section{RESUMO}

Toxicidade de zinco para espécies dos gêneros Pseudomonas, Escherichia, Proteus, Bacillus e Arthrobacter isoladas de um rio tropical e de um efluente de refinaria de petróleo foi avaliada utilizando o teste de inibição de atividade de desidrogenase (TTC). Em concentrações suficientes, o zinco é tóxico para as células bacterianas e a exposição das células ao íon zinco resultou na repressão da atividade de desidrogenase. Os padrões desses efeitos tóxicos podem ser matematicamente descritos com base em modelos logísticos de dose-resposta de forma semelhante à não inibição competitiva de enzimas. A concentração limiar acima da qual o efeito tóxico foi observado variou de $0,008 \mathrm{mM}$ para Pseudomonas sp. DAF1 até $0,364 \mathrm{mM}$ para Proteus sp. PLK2. Os coeficientes de inibição $K_{i}$ apresentaram correlação com o $\mathrm{IC}_{50}$ e indicaram que a toxicidade do zinco é dependente do organismo. Os limiares de $K_{i}$ e de toxicidade previstos a partir das equações são comparáveis e são indicadores adequados para a análise cinética da toxicidade do zinco contra as bactérias.

Palavras-chave: zinco; atividade de desidrogenase; limiares de toxicidade de efluentes de refinarias; coeficiente de inibição.

\section{INTRODUCTION}

Zinc is an essential trace element required for optimal growth and metabolism of microorganisms (Borst-Pauwels, 1981; Ji and Silver, 1995). Although zinc is a component or activator of some enzymes, it becomes inhibitory to cellular activities at elevated concentrations (Babich and Stotzky, 1978; Gadd, 1993; Nweke et al., 2006). Zinc toxicity is caused by its interaction with sulfhydryl groups and other important enzyme radicals as well 
as other proteins. Zinc is known to be a potent inhibitor of the respiratory electron transport systems of bacteria and eukaryotic organisms (Kasahara and Anraku, 1974; Beard et al., 1995; Choudhury and Srivastava, 2001). The intracellular concentrations of zinc must be finely adjusted to prevent either zinc deprivation or toxicity. Although microorganisms have mechanisms for homeostasis of toxic metals, there is a need to regulate the concentrations of metals in laboratory culture media, industrial bioprocess systems or natural ecosystems. To achieve this, adequate assessment of toxicity using microbial indicators is needed. Toxicity of zinc to microorganisms has been widely studied by quantifying observable metabolic changes such as, inhibition of growth, bioluminescence, dehydrogenase activity, nitrification etc. (Babich and Stotzky, 1978; Anderson et al., 1988; Kafka et al., 1997; Falih, 1998, Grunditz et al., 1998; Orji et al., 2008). However, kinetics of the toxic effects of metals has been studied to a lesser extent (Lewandowski et al., 1985; Volskay and Leslie Grady, 1988; Mazierski, 1994, Ren and Frymier, 2003). In this study, kinetics of the toxic effect of zinc to bacteria isolated from river water, river sediment and petroleum refinery wastewater were evaluated using dehydrogenase activity inhibition data.

\section{MATERIALS AND METHODS}

\subsection{Bacterial strains}

Bacterial strains were isolated from Port Harcourt petroleum refinery wastewater and New Calabar River, Port Harcourt, southeastern Nigeria. The method of isolation and identification of the bacterial strains was as described elsewhere (Nweke et al., 2006; 2007).

\subsection{Dehydrogenase assay}

Dehydrogenase activity was determined using 2,3,5-triphenyltetrazolium chloride as the artificial electron acceptor, which is reduced to red-coloured triphenylformazan (TPF). The assay was done in 3-ml volume of nutrient broth-glucose-TTC medium supplemented with varying concentrations of $\mathrm{Zn}^{2+}$ as $\mathrm{ZnSO}_{4}$ in separate screw-capped test tubes. Portions $(0.3$ $\mathrm{ml})$ of washed bacterial suspensions $\left(\mathrm{A}_{420}=0.5\right)$ were inoculated into triplicate glass tubes containing $2.5 \mathrm{ml}$ of phthalate-buffered $(\mathrm{pH} \mathrm{6)}$ nutrient broth glucose medium amended with $\mathrm{Zn}^{2+}$ and $0.2 \mathrm{ml}$ of $0.4 \%(\mathrm{w} / \mathrm{v})$ TTC in deionized distilled water was added to each tube to obtain final $\mathrm{Zn}^{2+}$ concentrations of $0.2-1.4 \mathrm{mM}$. The final concentrations of nutrient broth and glucose in the medium were $2 \mathrm{mg} / \mathrm{ml}$ each. The controls consisted of the isolates and the media without $\mathrm{Zn}^{2+}$. The reaction mixtures were incubated under static conditions at room temperature $\left(28 \pm 2{ }^{\circ} \mathrm{C}\right)$ for $24 \mathrm{~h}$. The TPF produced was extracted in $4 \mathrm{ml}$ of amyl alcohol and determined spectrophotometrically at $500 \mathrm{~nm}$ absorption maxima.

\subsection{Data analysis}

Inhibition of dehydrogenase activity by $\mathrm{Zn}^{2+}$ was calculated relative to the control as shown in Equation 1. The inhibition data generated are fitted into the kinetic models, Equation 2 (Kroiss et al. 1992; Juliastuti et al., 2003), Equation 3 (Ren and Frymier, 2003) and Equation 4 (Brains and Cousens, 1989; Abbondanzi et al., 2003). The kinetic parameters were estimated by iterative minimization of least squares using Levenberg-Marquardt algorithm of Table Curve 2D. All regression was done using the mean data and standard deviations. The Pearson product-moment correlation, linear regression analysis, t-test and analysis of variance (ANOVA) were done using Microsoft Excel 2003. The logistic dose-response functions, Equation 2 and Equation 4 were used to estimate the toxicity thresholds, $\mathrm{IC}_{20}, \mathrm{IC}_{50}$ and $\mathrm{IC}_{80}$ which are the concentrations of $\mathrm{Zn}^{2+}$ that inhibited dehydrogenase activity by 20,50 and $80 \%$ respectively. Pearson product-moment correlation was used to compare the inhibition constant 
$\left(K_{i}\right)$ estimated from Equation 2 and Equation 3 and the toxicity thresholds estimated from Equation 2 and Equation 4.

$$
\begin{aligned}
& \text { Inhibition }(\%)=\left(\frac{C_{A}-T_{A}}{C_{A}}\right) \times 100 \\
& \text { Inhibition }(\%)=\left(1-\frac{1}{1+\frac{I^{K I}}{K_{i}}}\right) \times 100 \\
& \operatorname{Inhibition}(\%)=\left(1-\frac{1}{1+\frac{I}{K_{i}}-\frac{a}{K_{i}}}\right) \times 100 \\
& \text { Inhibition }(\%)=\frac{a_{L}}{1+\left(\frac{I}{b}\right)^{c}}
\end{aligned}
$$

where: $C_{A}=$ the absorbance of TPF produced in control test (without zinc); $T_{A}=$ absorbance of TPF produced in the test with different concentrations of zinc; $I=$ Inhibitor concentration $(\mathrm{mM}) ; K_{i}=$ inhibition constant $(\mathrm{mM}) ; K I=$ dimensionless inhibition parameter; $a=$ threshold concentration above which toxic effect is observed (mM); $a_{L}=$ maximum inhibition $(\%) ; b=$ slope parameter indicating the inhibition rate $(\mathrm{mM}) ; c=$ dimensionless inhibition parameter.

Equation 3 assumes that $\mathrm{Zn}^{2+}$ represses bacterial dehydrogenase activity by inhibiting the rate-determining step in the formation of triphenyl formazan in a manner similar to noncompetitive inhibition of enzymes. In this case, the rate-determining step is the influx of electron to 2,3,5-triphenyltetrazolium chloride to form triphenyl formazan. This is catalyzed by a number of dehydrogenases, a battery of enzymes that transfer hydrogen and electron from substrate to 2,3,5-triphenyltetrazolium chloride (Rossel et al., 1997). Ren and Frymier (2003) have described the derivation of the model using bioluminescence inhibition data. A factor of 100 is added to the model to allow for the representation of repression of dehydrogenase activity in percentage.

\section{RESULTS AND DISCUSSION}

The New Calabar River is a short tidal coastal river situated in the Niger delta region of Nigeria. The river is impacted by effluent discharges from industries sited along its banks (Okpokwasili and Odokuma, 1993; Odokuma and Okpokwasili, 1997). Heavy metal resistant bacteria from this river have been reported (Odokuma and Ijeoma, 2003a, 2003b). More recently, the zinc content of the New Calabar River water and sediment were reported to be 5 $\mathrm{mg} / \mathrm{l}$ and $65.8 \mathrm{mg} / \mathrm{kg}$ respectively (Nweke et al., 2007). The petroleum refinery effluent contains zinc at concentrations ranging from $0.02 \mathrm{mg} / \mathrm{l}$ in the rotary biodisk to $0.13 \mathrm{mg} / \mathrm{l}$ in the raw wastewater.

The selected bacterial strains used in this study were Escherichia sp. PLK1, Proteus sp. PLK2 and Pseudomonas sp. PLK5 isolated from the river water as well as Bacillus sp. SED1 and Arthrobacter sp. SED4 isolated from the river sediment. The petroleum refinery effluent 
bacteria are Pseudomonas sp. DAF1, Pseudomonas sp. RWW2, Bacillus sp. DISK1 and Escherichia sp. DISK2. These bacteria are preponderant in their respective sources.

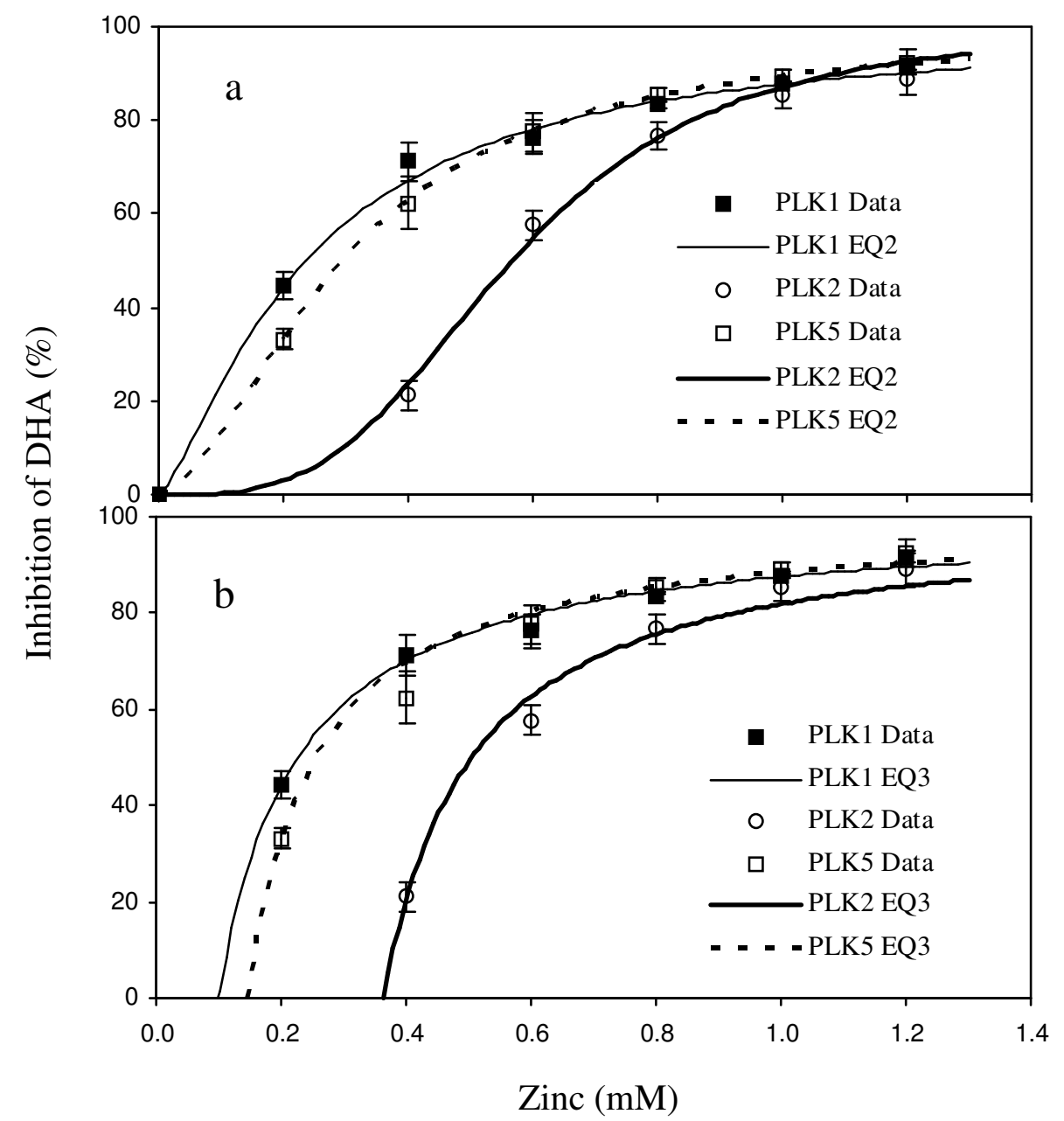

Figure 1. Effects of zinc on dehydrogenase activity (DHA) of Escherichia sp. PLK1, Proteus sp. PLK2 and Pseudomonas sp. PLK5 isolated from river water. The data points and bars represent experimental data mean \pm standard deviation, and the dotted and continuous lines represent the data fit obtained with Equation 2 (a) and Equation 3 (b).

The effects of $\mathrm{Zn}^{2+}$ in terms of its relative inhibition of dehydrogenase activity in the bacterial strains are shown in Figures 1-3. The responses of the river water bacteria are dependent on the concentration of $\mathrm{Zn}^{2+}$. In these bacterial strains, dehydrogenase activity was

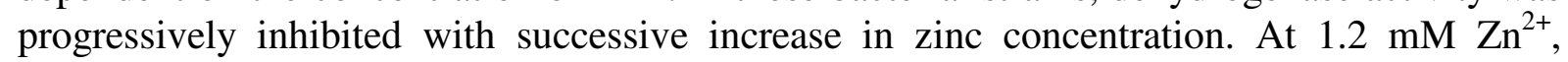
dehydrogenase activities in Escherichia sp. PLK1, Proteus sp. PLK2 and Pseudomonas sp. PLK5 were inhibited by $91.702 \pm 1.087 \%, 89.066 \pm 3.584 \%$ and $92.384 \pm 2.798 \%$, respectively. Similarly, dose-dependent response was observed with sediment bacteria (Figure 2). In Bacillus sp. SED1, the dehydrogenase activity was progressively inhibited, and $89.182 \pm$ $0.000 \%$ inhibition was observed at $1.0 \mathrm{mM}$. For Arthrobacter sp. SED4, total $(100 \%)$ inhibition of dehydrogenase activity occurred at $1.2 \mathrm{mM} \mathrm{Zn}^{2+}$. The refinery effluent bacterial isolates were equally sensitive to toxicity of $\mathrm{Zn}^{2+}$ (Figure 3 ). The percentage inhibition of dehydrogenase activity increased with successive increase in the concentration of $\mathrm{Zn}^{2+}$. This inhibition gradually increased in the case of Pseudomonas sp. RWW2 and Pseudomonas sp. DAF1. On the other hand, in the case of Bacillus sp. DISK1 and Escherichia DISK2, the inhibition increased sharply in the range of 0.05 to $0.2 \mathrm{mM} \mathrm{Zn}^{2+}$. In Bacillus sp. DISK1, 0.1 
$\mathrm{mM}$ resulted in $84.673 \pm 3.199 \%$ inhibition of dehydrogenase activity, while $0.2 \mathrm{mM}$ inhibited dehydrogenase activity by $63.333 \pm 0.442 \%$ in Escherichia sp. DISK2. In both organisms, total inhibition of dehydrogenase activity occurred at $0.8 \mathrm{mM}$. Inhibition of dehydrogenase activity reported herein corroborates previously reported toxic effect of $\mathrm{Zn}^{2+}$ at high concentrations (Ji and Silver, 1995; Rensing et al., 1997). Although zinc is a trace element, it is toxic in excess of required concentration. Zinc is a potent inhibitor of respiratory activities in microorganisms (Kleiner, 1978; Kasahara and Anraku, 1974; Pérez-Garcia et al., 1993; Beard et al., 1995). Zinc ion concentrations of $0.0001-0.01 \mathrm{mM}$ are required for optimal growth of most microorganisms in vitro (Sugarman, 1983).

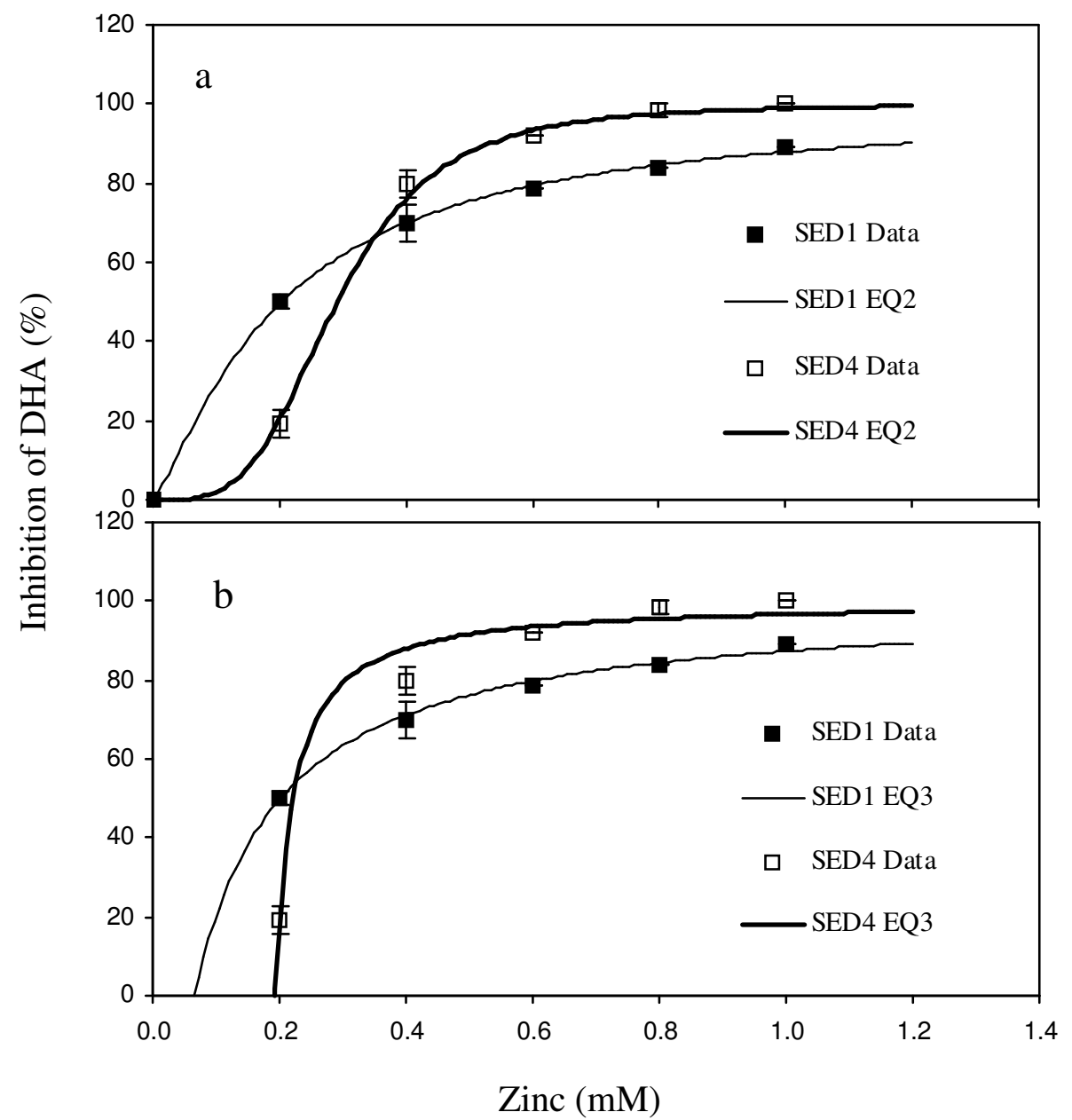

Figure 2. Effects of zinc on dehydrogenase activity (DHA) of Bacillus sp. SED1 and Arthrobacter sp. SED4 isolated from river sediment. The data points and bars represent experimental data mean \pm standard deviation, and the continuous lines represent the data fit obtained with Equation 2 (a) and Equation 3 (b). 


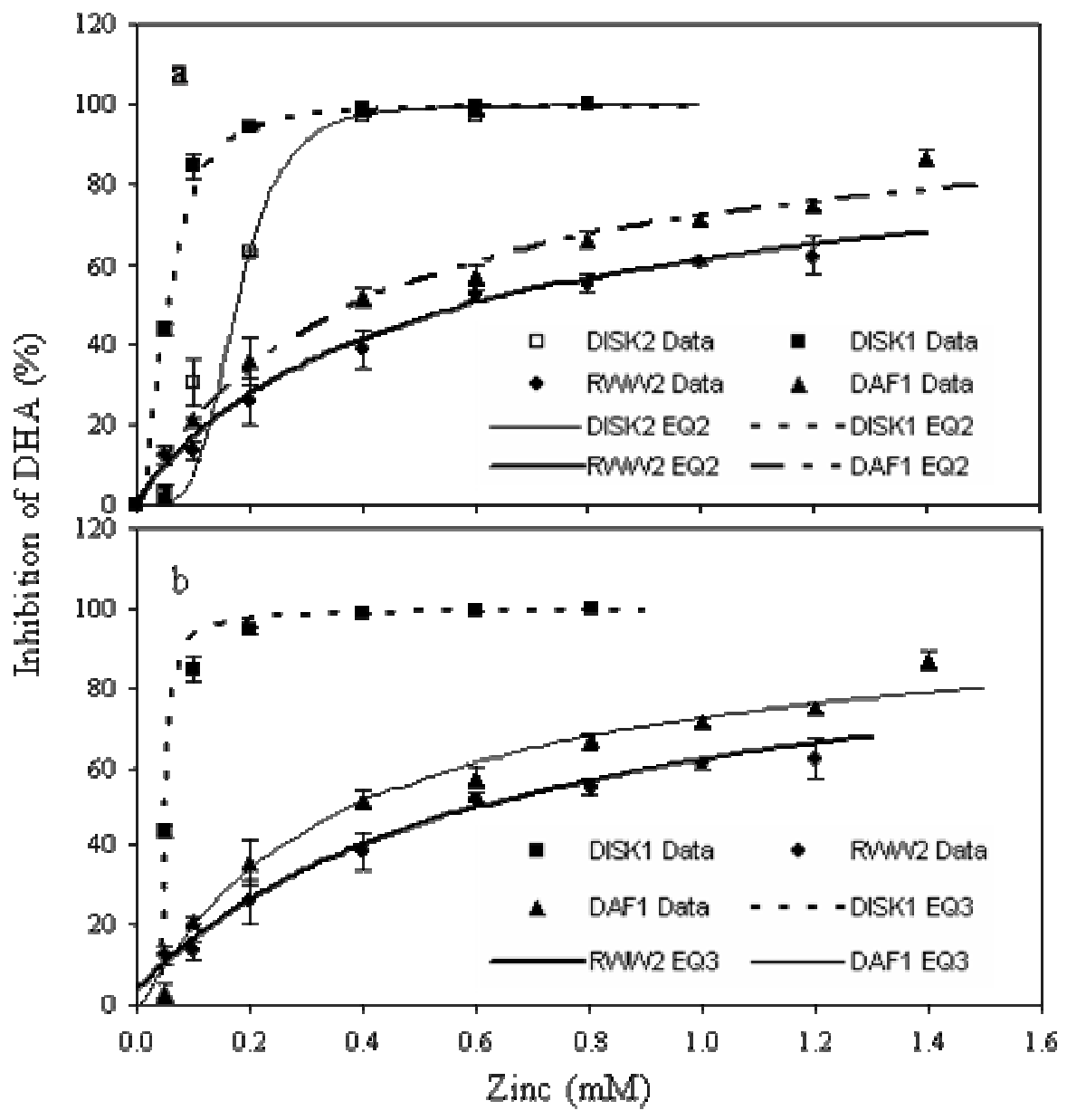

Figure 3. Effects of zinc on dehydrogenase activity (DHA) of Pseudomonas sp. DAF1, Pseudomonas sp. RWW2, Bacillus sp. DISK1 and Escherichia sp. DISK2 isolated from petroleum refinery wastewater. The data points and bars represent experimental data mean \pm standard deviation. The continuous and broken lines represent the data fit obtained with Equation 2 (a) and Equation 3 (b).

The dose-response patterns of the bacterial strains are describable by kinetic models with high coefficient of regression $\left(\mathrm{R}^{2}>0.98\right)$. The inhibition coefficient $\left(K_{i}\right)$ and toxicity threshold concentration $(a)$ values are shown in Table 1 . The results presented in Table 1 indicated that the inhibition of dehydrogenase activity varied and dependent on the bacteria. Pseudomonas sp. RWW2 had the highest $K_{i}$ of $0.626 \mathrm{mM}$ while Escherichia sp. DISK2 had the lowest $K_{i}$ of $0.0005 \mathrm{mM}$. The inverse of the inhibition coefficient $K_{i}$ represents the affinity of the enzyme to the inhibitor. Small $K_{i}$ values imply that there is a strong affinity between the enzyme and the inhibitor and thus the enzyme will be more strongly inhibited for a given inhibitor concentration (Ren and Frymier, 2003). Likewise, higher $K_{i}$ means lower toxicity and higher $\mathrm{IC}_{50}$. Therefore, in terms of $K_{i}$, Pseudomonas sp. RWW2 is the most tolerant while Escherichia sp. DISK2 is the most sensitive bacteria. The linear regression of the $\mathrm{IC}_{50}$ and $K_{i}$ predicted from Equation 2 gave high $\mathrm{R}^{2}$ value of 0.8099 , indicating good relationship between $K_{i}$ and $\mathrm{IC}_{50}$ (Figure 4). Also, the association between the $\mathrm{IC}_{50}$ and $K_{i}$ using the Pearson's product moment correlation coefficient $(r=0.8999)$ indicated that both parameters showed strong positive correlation. Ren and Frymier (2003) observed this kind of agreement between $K_{i}$ and $\mathrm{IC}_{50}$ during toxicity assessment of metals against luminescent Vibrio fischeri. Although the mechanism of zinc inhibition was not investigated in this study, it is reasonable to assume 
that the inhibition of dehydrogenase enzyme activity is similar to the non-competitive inhibition of enzymes. Zinc ion is not substrate analog and could not have bound competitively to the active site of dehydrogenase enzymes. According to inhibition coefficient $\left(K_{i}\right)$, the order of sensitivity of the isolates to toxicity of zinc is Escherichia sp. DISK2 > Bacillus sp. DISK1 > Arthrobacter sp. SED4 > Pseudomonas sp. PLK5 > Bacillus sp. SED1 $>$ Escherichia sp. PLK1 > Proteus sp. PLK2 > Pseudomonas sp. DAF1 > Pseudomonas sp. RWW2. Relatively, low concentration of zinc is required to inhibit dehydrogenase activity in refinery effluent bacteria. Similarly, Bacillus and Escherichia species of New Calabar River, having toxicity thresholds of 0.066 and $0.099 \mathrm{mM}$ respectively would also be inhibited at low concentrations of zinc. Pearson product-moment correlation coefficient $(r=-0.5098)$ indicated poor negative correlation between the toxicity threshold, $a$, and $K_{i}$. Although the minimum concentrations of $\mathrm{Zn}^{2+}$ that would inhibit dehydrogenase activity in the organisms were not determined experimentally, it would be some concentrations just above the respective toxicity threshold.

Table 1. Kinetic parameter estimates for zinc inhibition of dehydrogenase activity in bacterial isolates.

\begin{tabular}{|c|c|c|c|c|c|c|c|c|}
\hline \multirow[b]{2}{*}{ Bacteria/Source } & \multicolumn{4}{|c|}{ Equation 2} & \multicolumn{4}{|c|}{ Equation 3} \\
\hline & KI & $\begin{array}{c}K_{i} \\
(\mathbf{m M})\end{array}$ & $\mathbf{R}^{2}$ & $\mathbf{R}^{2}$ Adj & $\begin{array}{c}a \\
(\mathrm{mM})\end{array}$ & $\begin{array}{c}K_{i} \\
(\mathbf{m M})\end{array}$ & $\mathbf{R}^{2}$ & $\mathbf{R}^{2}$ Adj \\
\hline $\begin{array}{l}\text { River water } \\
\text { Escherichia sp. PLK1 }\end{array}$ & 1.365 & 0.140 & 0.9864 & 0.9773 & 0.099 & 0.128 & 0.9760 & 0.9600 \\
\hline Proteus sp. PLK2 & 3.366 & 0.148 & 0.9911 & 0.9822 & 0.364 & 0.141 & 0.9835 & 0.9669 \\
\hline Pseudomonas sp. PLK5 & 1.768 & 0.117 & 0.9998 & 0.9996 & 0.145 & 0.111 & 0.9950 & 0.9916 \\
\hline River sediment & & & & & & & & \\
\hline Bacillus sp. SED1 & 1.245 & 0.138 & 0.9939 & 0.9879 & 0.066 & 0.135 & 0.9882 & 0.9763 \\
\hline $\begin{array}{l}\text { Arthrobacter sp. SED } 4 \\
\text { Petroleum refinery effluent }\end{array}$ & 3.645 & 0.011 & 0.9963 & 0.9866 & 0.193 & 0.028 & 0.9616 & 0.9232 \\
\hline Pseudomonas sp. DAF1 & 1.023 & 0.379 & 0.9899 & 0.9865 & 0.008 & 0.373 & 0.9903 & 0.9870 \\
\hline Pseudomonas sp. RWW2 & 0.887 & 0.626 & 0.9884 & 0.9838 & -0.025 & 0.627 & 0.9869 & 0.9817 \\
\hline Bacillus sp. DISK1 & 2.119 & 0.002 & 0.9958 & 0.9930 & 0.047 & 0.004 & 0.9863 & 0.9772 \\
\hline Escherichia sp. DISK2 & 4.396 & 0.0005 & 0.9953 & 0.9905 & - & - & - & - \\
\hline
\end{tabular}

The $K_{i}$ values obtained from Equation 2 and Equation 3 were compared. This comparison is represented graphically in Figure 5a. The Pearson product-moment correlation coefficient $(r)$ is 0.9991 , indicating near perfect correlation. Linear regression analysis of the $K_{i}$ values yielded the relationship, $K_{i}$ (Equation 2$)=1.0079 K_{i}$ (Equation 3) with high coefficient of regression of 0.9983 . The result indicates that $K_{i}($ Equation 2$) \approx K_{i}$ (Equation 3$)$. This is further elucidated by the plot of the function, $K_{i}$ (Equation 2) $=K_{i}$ (Equation 3) shown in Figure 5a. The linear regression line of $K_{i}$ (Equation 2) versus $K_{i}$ (Equation 3 ) coincides with the function $K_{i}($ Equation 2$)=K_{i}$ (Equation 3). This indicates that the kinetic model (Equation 3) proposed by Kroiss et al. (1992) could be used not only as a suitable model to predict the inhibition coefficient $K_{i}$ but also the concentration of a toxicant above which there is toxic effect. Although the model predicts negative inhibition of dehydrogenase activity for $I<a$, the model was not used to describe the effects of toxicant at concentrations below the threshold concentration. However, at concentrations below the threshold, hormesis or stimulation of dehydrogenase activity is expected. In Proteus sp. PLK2, $\mathrm{Zn}^{2+}$ stimulated dehydrogenase activity by $7.453 \pm 3.00 \%$ at $0.2 \mathrm{mM}$ (data not shown in the plots).

The inhibition thresholds, $\mathrm{IC}_{20}, \mathrm{IC}_{50}$ and $\mathrm{IC}_{80}$ derived from the logistic models Equation 2 and Equation 4 are shown in Table 2. The median inhibitory concentrations $\left(\mathrm{IC}_{50}\right)$ of $\mathrm{Zn}^{2+}$ derived from Equation 4 ranged from $0.055 \mathrm{mM}$ for Bacillus sp. DISK1 to $0.568 \mathrm{mM}$ for 
NWEKE, C. O. Kinetics of zinc toxicity to environmental bacterial isolates. Ambi-Agua, Taubaté, v. 4, n. 3, p. 23-34, 2009. (doi:10.4136/ambi-agua.100)

Pseudomonas sp. RWW2. According to $\mathrm{IC}_{50}$, the order of sensitivity is Bacillus sp DISK1 > Escherichia sp. DISK2 > Bacillus sp. SED1 > Escherichia sp. PLK1 > Arthrobacter sp. SED4 $>$ Pseudomonas sp. PLK5 > Pseudomonas sp. DAF1 > Proteus sp. PLK2 > Pseudomonas sp. RWW2. $\mathrm{IC}_{50}$ of zinc against Pseudomonas fluorescens in a TTC-dehydrogenase assay have been reported to vary from 0.64 to $1.27 \mathrm{mg} / \mathrm{l}(0.01-0.02 \mathrm{mM})$ (Abbondanzi et al., 2003). In a viability assay based on standard plate count, $0.25 \mathrm{mM}$ of zinc killed $43 \%$ of soil bacteria (Keeling and Cater, 1998). A 100\% lethal concentration of zinc ranging from $5-250 \mathrm{mg} / \mathrm{l}$ $(0.077-0.385 \mathrm{mM})$ was reported for bacteria extracted from a pristine soil (Angle et al., 1993).

Table 2. Toxicity thresholds $(\mathrm{mM})$ of zinc estimated from the kinetic models Equation 2 and Equation 4.

\begin{tabular}{|c|c|c|c|c|c|c|}
\hline Bacteria/ Source & $\mathrm{IC}_{20}$ & $\mathrm{IC}_{50}$ & $\mathrm{IC}_{80}$ & $\mathbf{R}^{2}$ & $\mathbf{R}^{2} \mathbf{a d j}$ & Fit Standard Error \\
\hline & \multicolumn{6}{|c|}{ Equation 2} \\
\hline River water & & & & & & \\
\hline Escherichia sp. PLK1 & 0.086 & 0.237 & 0.654 & 0.9864 & 0.9773 & 0.8259 \\
\hline Proteus sp. PLK2 & 0.375 & 0.567 & 0.856 & 0.9911 & 0.9822 & 3.0489 \\
\hline Pseudomonas sp. PLK5 & 0.135 & 0.297 & 0.650 & 0.9998 & 0.9997 & 0.3424 \\
\hline \multicolumn{7}{|l|}{ River sediment } \\
\hline Bacillus sp. SED1 & 0.067 & 0.203 & 0.619 & 0.9939 & 0.9879 & 1.1091 \\
\hline Arthrobacter sp. SED4 & 0.199 & 0.291 & 0.426 & 0.9933 & 0.9866 & 1.5628 \\
\hline \multicolumn{7}{|l|}{ Petroleum refinery effluent } \\
\hline Pseudomonas sp. DAF1 & 0.100 & 0.388 & 1.505 & 0.9899 & 0.9865 & 3.0614 \\
\hline Pseudomonas sp. RWW2 & 0.124 & 0.590 & 2.816 & 0.9884 & 0.9838 & 2.1157 \\
\hline Bacillus sp. DISK1 & 0.029 & 0.055 & 0.107 & 0.9958 & 0.9930 & 0.1787 \\
\hline Escherichia sp. DISK2 & 0.129 & 0.177 & 0.242 & 0.9953 & 0.9905 & 0.8093 \\
\hline & \multicolumn{6}{|c|}{ Equation 4} \\
\hline \multicolumn{7}{|l|}{ River water } \\
\hline Escherichia sp. PLK1 & 0.070 & 0.233 & 0.686 & 0.9916 & 0.9791 & 0.7472 \\
\hline Proteus sp. PLK2 & 0.392 & 0.556 & 0.845 & 0.9997 & 0.9987 & 0.6999 \\
\hline Pseudomonas sp. PLK5 & 0.136 & 0.296 & 0.647 & 0.9998 & 0.9997 & 0.3784 \\
\hline $\begin{array}{l}\text { River sediment } \\
\text { Bacillus sp. SED1 }\end{array}$ & 0.050 & 0.199 & 0.643 & 0.9990 & 0.9960 & 0.5547 \\
\hline Arthrobacter sp. SED4 & 0.197 & 0.292 & 0.432 & 0.9944 & 0.9776 & 1.7543 \\
\hline \multicolumn{7}{|l|}{ Petroleum refinery effluent } \\
\hline Pseudomonas sp. DAF1 & 0.100 & 0.409 & 1.414 & 0.9902 & 0.9843 & 3.2562 \\
\hline Pseudomonas sp. RWW2 & 0.128 & 0.568 & 8.061 & 0.9904 & 0.9832 & 2.1100 \\
\hline Bacillus sp. DISK1 & 0.031 & 0.055 & 0.100 & 0.9977 & 0.9942 & 0.1532 \\
\hline Escherichia sp. DISK2 & 0.153 & 0.185 & 0.226 & 0.9990 & 0.9959 & 0.4626 \\
\hline
\end{tabular}

The IC values obtained from Equation 2 and Equation 4 were compared. The Pearson product-moment coefficients $(r)$ were $0.9944,0.9981$ and 0.9387 respectively for $\mathrm{IC}_{20}, \mathrm{IC}_{50}$ and $\mathrm{IC}_{80}$ derived from Equation 2 and Equation 4. The relationships are shown in Figures $5 \mathrm{~b}-$ d. Although Equation 4 described the experimental data better, as are indicated by the $\mathrm{R}^{2}$ and fit standard error values, Equation 2 also proved to be suitable for predicting inhibition thresholds. In addition, the t-test $(\mathrm{P}<0.01)$ indicated that there were no significant difference between the IC values obtained from Equation 2 and Equation 4. In all determinations, the linear regression coefficient $\left(\mathrm{R}^{2}\right)$ are greater than 0.98 and the regression line coincided with the function $\mathrm{IC}_{\mathrm{x}}$ (Equation 2) $=\mathrm{IC}_{\mathrm{x}}$ (Equation 4). It is noteworthy that Equation 2 is derived from the descending form of Equation 4, $y=a /\left(1+(x / b)^{c}\right)$ with a positive value of $c$. Equation 4 is ascending form with a negative value of $c$. The maximum value of $y$ (\% inhibition of 
NWEKE, C. O. Kinetics of zinc toxicity to environmental bacterial isolates. Ambi-Agua, Taubaté, v. 4, n. 3, p. 23-34, 2009. (doi:10.4136/ambi-agua.100)

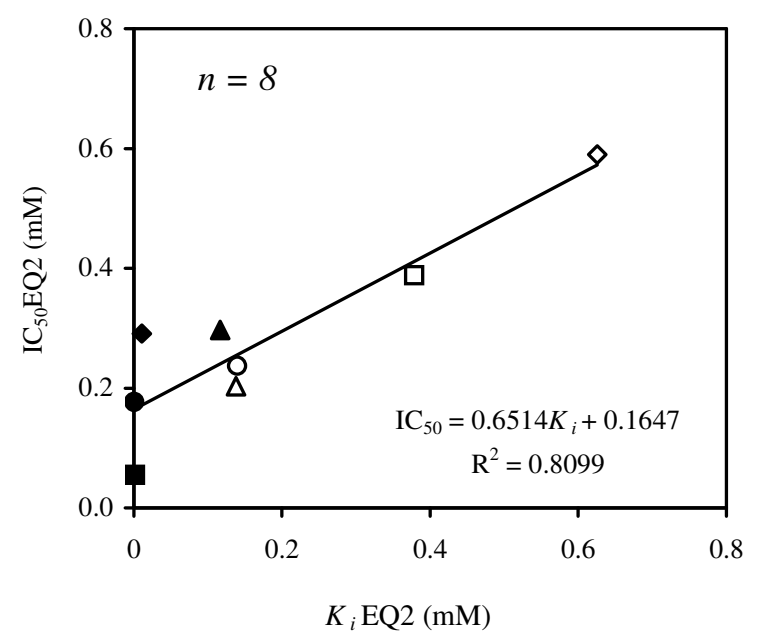

Figure 4. Comparison between $K_{i}$ and $\mathrm{IC}_{50}$ values estimated from the kinetic model EQ2. Data represents: Escherichia sp. PLK1 (O); Pseudomonas PLK5 ( $\mathbf{\Delta})$; Bacillus sp. SED1 $(\Delta)$; Pseudomonas DAF1 ( $\square)$; Pseudomonas sp. RWW2 ( $\diamond)$; Arthrobacter SED $4(\diamond)$; Bacillus sp. DISK1 (๘) and Escherichia sp. DISK2 (•) linear regression.
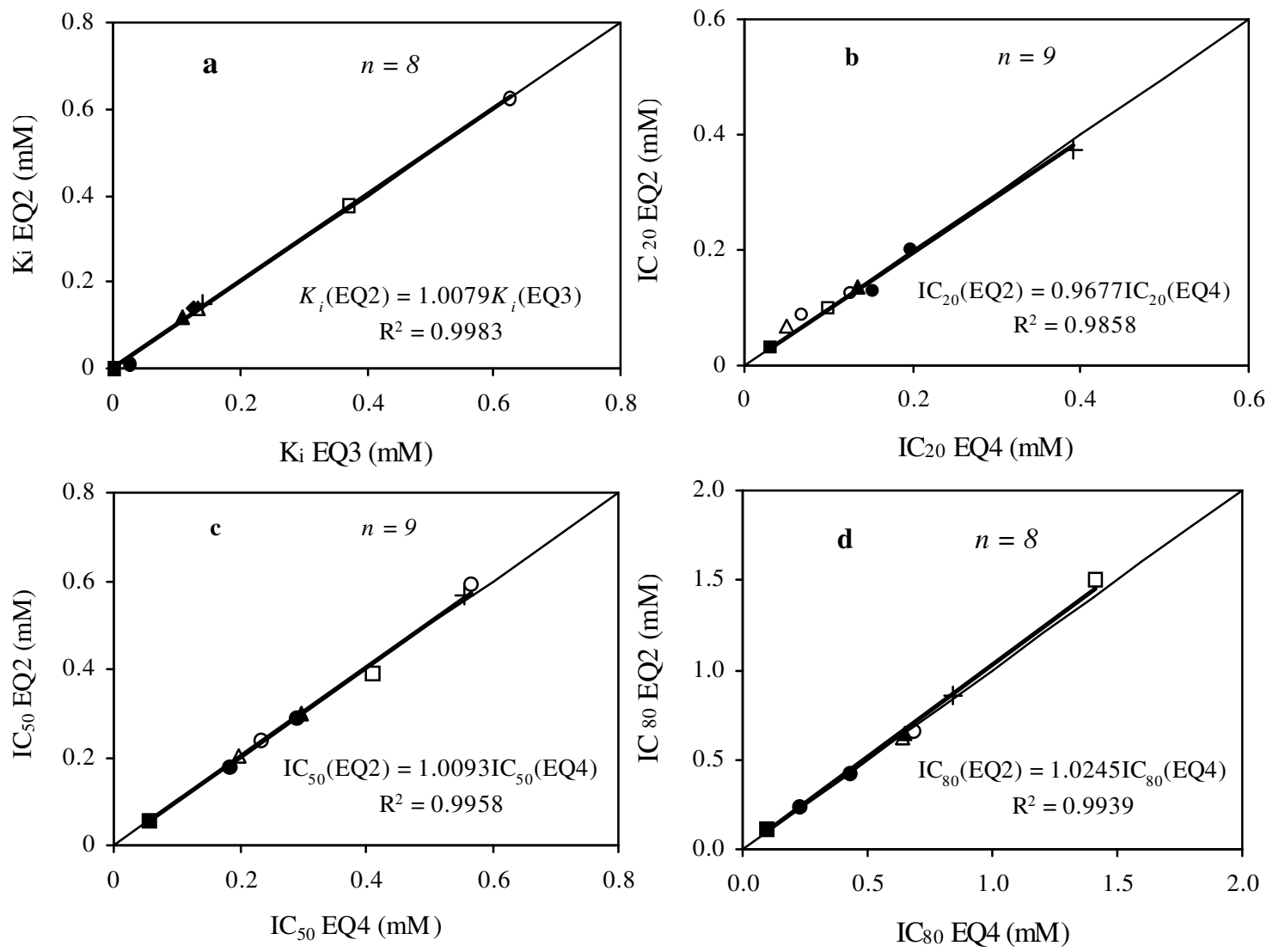

Figure 5. Comparisons between $K_{i}$ values estimated from the kinetic models Equation 2 and Equation 3 (a) and between toxicity thresholds, $\mathrm{IC}_{20}, \mathrm{IC}_{50}$ and $\mathrm{IC}_{80}$ (b-d) estimated from logistic dose-response models EQ2 and EQ4 . Data represents: Escherichia sp. PLK1 (०); Proteus sp.

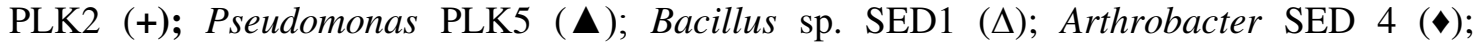
Pseudomonas DAF1 ( $\square)$; Pseudomonas sp. RWW2 $(\diamond)$; Bacillus sp. DISK1 (๘) and Escherichia sp. DISK2 $(\bullet)$. The thin line represents the function $y=x$ and the thick line represents linear regression of data. 
dehydrogenase activity) is set at $100 \%$ in equation 2 (Equation 2) and allowed as a parameter to be determined by successive iteration process in Equation 4 . Thus the slight difference between the predicted values of equations 2 and 4 is brought about by the maximum value of the percentage inhibition used. Equation 2 is particularly applicable when there is no stimulation of enzyme activity at low concentrations of the test toxicant. The 2-way ANOVA showed that the dehydrogenase activity varied significantly $(\mathrm{p}<0.01)$ with bacteria type and the concentrations of zinc.

\section{CONCLUSION}

The kinetics of zinc inhibition of dehydrogenase activity in bacterial strains can be mathematically described using logistic functions and as a non-competitive inhibition of ratedetermining enzymatic reaction. There was agreement between $K_{i}$ values obtained from the logistic function (Equation 2) and Equation 3, describing non-competitive inhibition of dehydrogenase activity. Also good agreement exists between the inhibition threshold concentrations (ICs) values predicted from Equation 2 and Equation 4. Additional information is provided by Equation 3 by predicting the respective threshold concentrations of zinc above which toxic effect is observed. These, represent the maximum concentration of zinc required for normal physiological activities of the bacteria. Thus, the information obtained from these kinetic models has bearing on the design and operation of bioprocess technologies, such as bioremediation, to prevent metal toxicity.

\section{REFERENCES}

ABBONDANZI, F.; CACHADA, A.; CAMPISI, T.; GUERRA, R.; RACCAGNI, M.; IACONDINI, A. Optimisation of a microbial bioassay for contaminated soil monitoring: bacterial inoculum standardisation and comparison with Microtox ${ }^{\circledR}$ assay Chemosphere, v. 53, p. $889-897,2003$.

ANDERSON, K.; KOOPMAN, B.; BITTON, G. Evaluation of INT-dehydrogenase assay for heavy metal inhibition of activated sludge. Water Res., v. 22, n. 3, p. 349 - 353, 1988.

ANGLE, J. S.; CHANEY, R. L.; RHEE, D. Bacterial resistance to heavy metals related to extractable and total metal concentrations in soil. Soil Biol. Biochem., v. 25, p. 1443 1446, 1993.

BABICH, H.; STOTZKY, G. Toxicity of zinc to fungi, bacteria and coliphages: influence of chloride ions. Appl. Environ. Microbiol., v. 36, p. 906-914, 1978.

BEARD, S. J.; HUGHES, M. N.; POOLE, R. K. Inhibition of the cytochrome bd-terminated NADH oxidase system in Escherichia coli K-12 by divalent metal cations. FEMS Microbiol. Lett., v. 131, p. 205-210, 1995.

BORST-PAUWELS, G. W. F. H. Ion transport in yeast. Biochim. Biophys. Acta., v. 650, p. $88-127,1981$.

BRAINS, P.; COUSENS, R. An equation to describe where there is stimulation of growth at low doses. Weed Research, v. 29, p. 93 - 96, 1989.

CHOUDHURY, R.; SRIVASTAVA, S. Zinc resistance mechanisms in bacteria. Current Science, v. 8, n.7, p. $768-775,2001$.

FALIH, A. M. Comparative toxicity of heavy metals to some yeasts isolated from Saudi Arabian soil. Bioresource Technol., v. 64, p. 193-198, 1998. 
GADD, G. M. Interactions of fungi with toxic metals. New Phytol., v. 124, p. 25 - 60, 1993.

GRUNDITZ, C.; GUMAELIUS, L.; DALHAMMER, G. Comparison of inhibition assays using nitrogen removing bacteria. Application to industrial wastewater. Water Res., v. 32, n.10, p. $2995-3000,1998$.

JI, G.; SILVER, S. Bacterial resistance mechanism for heavy metals of environmental concern. J. Ind. Microbiol., v. 14, p. 64 - 168, 1995.

JULIASTUTI, S. R.; BAEYENS, J.; CREEMERS, C. Inhibition of nitrification by heavy metals and organic compounds: The ISO 9509 test. Environ. Eng. Sci., v. 20, n. 2, p. 79 - 90, 2003.

KAFKA, Z.; PUNCOCHAROVA, J.; SVADLENKA, J.; KURAS, M. Determination of acute toxicity of heavy metals. Toxicol. Environ. Chem., v. 63, p. 119-124, 1997.

KASAHARA, M.; ANRAKU, Y. Succinate and NADH oxidase systems of Escherichia coli membrane vesicles: mechanism of selective inhibition of the system by zinc ions. $\mathbf{J}$. Biochem., v. 76, p. $967-976,1974$.

KEELING, A. A.; CATER G. L. F. Toxicity of copper, lead, nickel and zinc in agar culture to aerobic, diazotrophic bacteria extracted from waste-derived compost. Chemosphere, v. 37, n. 6, p. 1073 - 1077, 1998.

KLEINER, D. Inhibition of respiratory system in Azotobacter vinelandi by divalent metal ions. FEBS Lett., v. 96, n. 2, p. 366 - 368, 1978.

KROISS, H.; SCHWEIGHOFFER, P.; FREY, W.; MATSCHE, N. Nitrification Inhibition: a source identification method for combined municipal and industrial wastewater treatment plant. Water Sci. Technol., v. 26, n. 5/6, p. 1135-1146, 1992.

LEWANDOWSKI, Z.; JANTA, K.; MAZIERSKI J. Inhibition coefficient (Ki) determination in activated sludge. Water Res., v. 19, p. 671- 674, 1985.

MAZIERSKI, J. Effect of chromium (CrVI) on the growth rate of denitrifying bacteria. Water Res., v. 28, p. 1981-1985, 1994.

NWEKE, C. O.; OKOLO, J. C.; NWANYANWU, C. E.; ALISI, C. S. Response of planktonic bacteria of New Calabar River to zinc stress. Afr. J. Biotechnol., v. 5, n. 8, p. 653-658, 2006.

NWEKE, C. O.; ALISI, C. S.; OKOLO, J. C.; NWANYANWU, C. E. Toxicity of zinc to heterotrophic bacteria from a tropical river sediment. Appl Ecol. Environ. Res., v. 5, n. 1, p. 123-132, 2007.

ODOKUMA, L. O.; IJEOMAH, S. O. Tolerance of bacteria to toxicity of heavy metals in the New Calabar River, Nigeria. Global J. Environ. Sci., v. 2, p. 128 - 132, 2003 a.

ODOKUMA, L. O.; IJEOMAH, S. O. Seasonal changes in the heavy metal resistant bacterial population of the New Calabar River. Global J. Pure Appl. Sci., v. 9, p. 425 - 433, 2003 b.

ODOKUMA, L. O.; OKPOKWASILI, G. C. Seasonal influences of the organic pollution monitoring of the New Calabar River, Nigeria. Environ. Monitor. Assess., v. 45, p. 43 $-56,1997$. 
OKPOKWASILI, G. C.; ODOKUMA, L. O. Seasonal influences on inorganic anion monitoring of the New Calabar River, Nigeria. Environ. Management, v. 17, p. 491 496, 1993.

ORJI, J. C.; NWEKE, C. O.; NWABUEZE, R. N.; ANYAEGBU, B.; CHUKWU, J. C.; CHUKWUEKE, C. P.; NWANYANWU, C. E. Impact of some divalent cations on periplasmic nitrate reductase and dehydrogenase enzymes of Escherichia, Pseudomonas and Acinetobacter species. Ambi-Agua,v. 3, n. 2, p. 5 - 18, 2008. (doi:10.4136/ambiagua.48)

PÉREZ-GARCIA, A.; CODINA, J. C.; CAZORIA, F. M.; DE VICENTE, A. Rapid respirometric toxicity test: sensitivity to metals. Bull. Environ. Contam. Toxicol., v. 50, p. $703-708,1993$.

REN, S.; FRYMIER, P. D. Kinetics of the toxicity of metals to luminescent bacteria. Adv. Environ. Res., v. 7, p. 537-547, 2003.

RENSING, C.; MITRA, R.; ROSEN, B. P. Insertional inactivated of $d s b A$ produces sensitivity to cadmium and zinc in Escherichia coli. J. Bacteriol., v. 179, n. 8, p. 2769 2771, 1997.

ROSSEL, D.; TARRADELlAS, J.; BITTON, G.; MOREL, H. Use of enzymes in ecotoxicology: a case for dehydrogenase and hydrolytic enzymes. In: TARRADELLAS, J.; BITTON, G.; ROSSEL, D. (Eds). Soil Ecotoxicology., CRC Lewis Boca Raton, Fla., p.179-192, 1997.

SUGARMAN, B. Zinc and infection. Rev. Infect. Dis., v. 138, p. 147, 1983.

VOLSKAY, V. T.; LESLIE GRADY, C. P. Toxicity of selected RCRA compounds to activated sludge microorganisms. J. Water Pollut. Control Fed., v. 60, n. 10, p. 18501856, 1988. 